\title{
CORRELATION BETWEEN THE CLINICAL PHONOAUDIOLOGICAL ASSESSMENT AND ELECTROMYOGRAPHIC ACTIVITY OF THE MASSETER MUSCLE
}

\author{
CORRELAÇÃO ENTRE A AVALIAÇÃO CLÍNICO-FONOAUDIOLÓGICA \\ E A ELETROMIOGRÁFICA DO MÚSCULO MASSETER
}

Daiana Cristina BIASOTTO'1, Daniela Ap. BIASOTTO-GONZALEZ ${ }^{2}$, Ivone PANHOCA ${ }^{3}$

\begin{abstract}
1- MSc, Graduate student (Master degree), Department of Children and Teenagers Health, State University of Campinas (UNICAMP).
2- DDS, Assistant Professor, Department of Physicaltherapy, University of Mogi das Cruzes.

3- PhD, Associate Professor, Department of Children and Teenagers Health, State University of Campinas (UNICAMP).
\end{abstract}

Corresponding address: Daiana Cristina Biasotto - Rua São Bento, 3099 - Bairro Santa Angelina - Cep.: 14802-290 - ARARAQUARA - SP Fone: (16):3336-3081 - cel: 9702-2922 - E-mail: daianabiasotto@ig.com.br

Received: February 1, 2005 - Modification: March 23, 2005 - Accepted: August 11, 2005

\begin{abstract}
$O$

bjective: The objective of this paper was to evaluate the specificity of masseter muscle palpation when compared to its electromyographic activity. Materials and Methods: Twenty-one young female adults, aged between 17 and 25, participated in this research. The speech therapy evaluation data were obtained by two speech therapists through masseter muscle palpation during isometric contraction, and the electromyographic exam was achieved by using bipolar superficial electrodes, positioned on the masseter muscle. The volunteers were instructed to chew the Parafilm $\mathbf{M}^{\circledR}$ material bilaterally and simultaneously. The capture of the electromiographic signals occurred during masseter muscle isometric contractions. The electrical activity study of the masticatory muscle was analyzed through the Root Mean Square value during its isotonic contraction. Statistical Analysis: All data were then submitted to Kappa statistical analysis. Results: The results of this study have shown a low correlation between palpation and electromyography (25\%), as well as between evaluators (40\%). Conclusion: According to the findings of the present study, it could be observed that the correlation between masseter muscle palpation and its electromyographic activity was very low, which allows to conclude that muscular palpation cannot effectively replace the eletromyographical exam, but complement it instead.

Uniterms: Electromyography; Palpation; Masseter muscle; Oral mobility.
\end{abstract}

\footnotetext{
RESUMO

$O$

bjetivo: Este trabalho teve como objetivo avaliar a correlação entre os resultados obtidos na palpação e os dados obtidos no exame eletromiográfico do músculo masseter. Material e método: Participaram deste estudo 21 adultos jovens do sexo feminino, idades entre 17-25 anos. Os dados da avaliação fonoaudiológica foram obtidos por meio da palpação do músculo masseter durante a contração isométrica por dois fonoaudiólogos e os dados eletromiográficos foram captados com a utilização de eletrodos de superfície bipolares posicionados no músculo masseter durante a contração isotônica, sendo os voluntários orientados a mastigar bilateral e simultaneamente o material Parafilme ${ }^{\circledR}$.O estudo da atividade elétrica do músculo mastigatório foi analisado pelo valor de RMS (Root Mean Square) na contração isotônica do músculo. Análise estatística: Todos os dados foram submetidos à análise estatística Kappa. Resultados: Os resultados deste estudo indicaram baixa correlação entre a palpação e a eletromiografia (25\%) e entre avaliadores (40\%). Conclusão: a partir dos achados do presente estudo, que a correlação entre os dados obtidos na palpação do músculo masseter em relação aos dados obtidos no exame eletromiográfico foi muito baixa. Os resultados indicam que a palpação muscular não substitui o exame eletromiográfico, devendo complementá-lo.

Unitermos: Eletromiografia; Palpação; Músculo masseter; Motricidade oral.
} 


\section{INTRODUCTION}

The masseter muscle is not only the most potent masticatory muscle but also the most evident. It is a large, thick, and rectangular muscle located on both sides of the face, having a deep and a superficial portion. The superficial portion has its origin on the anterior two thirds of the zygomatic arch, and the deep portion on the posterior third and internal border of the zygomatic arch. Its function is to elevate the mandible, and its innervation is provided by the masseteric nerve, branch of the cranial nerve V (Bianchini ${ }^{4}$, 2000; Fehrenbach and Herring ${ }^{11}$, 1996).

Palpation is defined as a method of feeling with the hands, which is used during physical assessment. The examiner touches and feels the patient's body part with the hands to assess the area, size, consistency, texture, tendons, as well as other parts of the body (Kennedy $\left.{ }^{15}, 2001\right)$.

According to Felicio ${ }^{12}$ (1999), palpation of the mandible elevator and depressor muscles completes the stomatognathic system assessment. Palpation reveals whether the musculature is reacting to the occlusal and/or functional unbalance, and even to emotional behavior in the muscles. With the pressure of the finger tips against the musculature, the existence of muscular tension or specific pain triggering spots can be observed.

As stated by Steenks and Wijer ${ }^{20}$ (1996), while performing muscular palpation the examiner should pay attention to the volume, tone, and muscle body modifications (edema, stiff areas), along with painful areas and pain triggering spots.

According to Okeson ${ }^{18}$ (1992), digital palpation (with the fingertips) is a widely accepted method to determine muscle tone and pain, besides being an easy and low-cost method to be used.

The electromyography is a generic term which expresses the method to register the electrical activity of a muscle while performing contraction. It may be used for a number of applications, mainly in the medical clinical area, to diagnose a neuromuscular or traumatic disease, and in rehabilitation, as a kinesiological tool to study the muscular function at specific activities (Amadio and Duarte ${ }^{1}, 1996$ ).

De Luca ${ }^{10}$ (1997) reports that the electromyographic signal acts as an indicator of the muscular activity initiation, which can also provide the firing sequence of one or more muscles performing a specific task. Other important information from the electromyographic signal is to indicate the contribution of the force of each individual muscle, as well as of muscular groups.

The kinesiological electromyography (EMG) is the most common procedure used to assess skeletal muscle function. Several studies (Clark, et al. ${ }^{8}$, 1981; Naeije and Hansson ${ }^{17}$, 1986; Carlson, et al. ${ }^{7}$, 1991; Berzin ${ }^{3}$, 1999; Biasotto-Gonzalez and Berzin ${ }^{5}$, 2004) have tried to demonstrate some electromyographic signal characteristics as an indication of muscular dysfunction.

The kinesiological electromyography represents a sensitive tool to assess muscular functions, and it has been used in the dental field since it was first researched by E. R. Moyers, in 1949, and lately in speech therapy with studies performed by Jardini ${ }^{13}$ (2001) and Rodrigues ${ }^{19}$ (2001).

The objective of this study is to correlate the masseter muscle electromyographic activity with its clinical assessment through palpation.

No former comparative studies were found in the literature focusing on the clinical assessment of the masseter muscle through palpation and the respective electromyographic assessment. Moreover, a study involving these two topics - in order to verify the agreement between them - is justified in considering the fact that palpation is a low-cost, widely used technique in clinical practice as an assessment tool in an attempt to evaluate muscular tension.

\section{MATERIALS AND METHODS}

\section{VOLUNTEERS}

Twenty-one (21) randomly chosen female teenagers and young adults participated in this study. They were healthy university students - ages ranging between 17 and 25 (mean $21 \pm 4$ years) - who had no complaints related to pain and were randomly chosen from the University of Mogi das Cruzes, in a city near São Paulo.

\section{EXCLUSION CRITERIA}

Individuals with absence of one or more teeth (except third molars) wearing any type of dental prosthesis, under 17 and over 25 years of age, males, and those who refused to sign the required Informed Consent Form to be part of the masters thesis were excluded from the study (Appendix 2).

\section{MATERIALS AND ASSESSMENT SHEET}

The following equipment and tools were used to carry out this research:

- Signal Conditioner Device, Lynx Electronics Ltd., 16 channels.

- Converter A/D Board, Model CAD 12/32, 12 bites, Lynx electronics Ltd.

- Software Aqdados, version 5.0 - Lynx Electronics Ltd.

- Computer Pentium I with HP Deskjet Printer, model 692C.

- Differential Active Surface Electrodes - Lynx Electronics Ltd.

- Ground Electrodes with Water Based Gel.

- Parafilm M® (Biasotto $\left.{ }^{6}, 2003\right)$.

- Speech Therapy Assessment Sheet (Appendix 1).

\section{PROCEDURES}

The aims of the research were clarified to all volunteers and they were asked to fill out the Informed Consent Form to be part of the masters thesis (Appendix 2). Palpation of the masseter muscle was included in the speech therapy assessment. At last, the electromyographic exam was performed at the University of Mogi das Cruzes (UMC) Electromyographic Laboratory premises. 


\section{SPEECH THERAPY PROCEDURES}

\section{SPEECH THERAPY ASSESSMENT}

Initially, an evaluation was performed by two speech therapists, specialists in Oral Mobility, by palpation. Afterwards, the volunteer was asked to perform maximal habitual intercuspation for 15 seconds (Kendall $\left.{ }^{14}, 1987\right)$. The masseter muscles were then palpated bilaterally to check for muscle tension and also whether there was a predominance of side. This would mean that one muscle was tenser than the muscle in the opposite side, or both would feature the same tension during isometric contraction.

The speech therapy assessment was performed by the two examiners, one immediately after the other. The EMG exam was performed soon afterwards.

After these two procedures, it was possible to compare and assess whether there was agreement. Results were recorded in the speech therapy assessment sheet (Appendix 1).

The masticatory muscle palpation was performed as follows:

- Masseter Muscle: sliding the fingers from its origin on the zygomatic arch to its insertion on the mandible during the teeth maximal intercuspation period $\left(\right.$ Okeson $^{18}{ }^{18}$ 1992).

\section{ELECTROMYOGRAPHIC SIGNAL COLLECTION}

\section{ELECTROMYOGRAPHIC INSTRUMENTATION}

In order to record the electromyographic exam, the analogous signals were amplified and prepared to be digitized in the Signal Conditioner Device (MCS 1000 - V2, Lynx), with 16 analogical inputs, DMA (Direct Memory Access) support, interfaced with a Pentium 1 computer, through the board of signal converter from Analogue to Digital (A/D) (model CAD 12/32, Lynx (Figure 1), with 12 resolution bits of dynamic band, and sampling frequency of

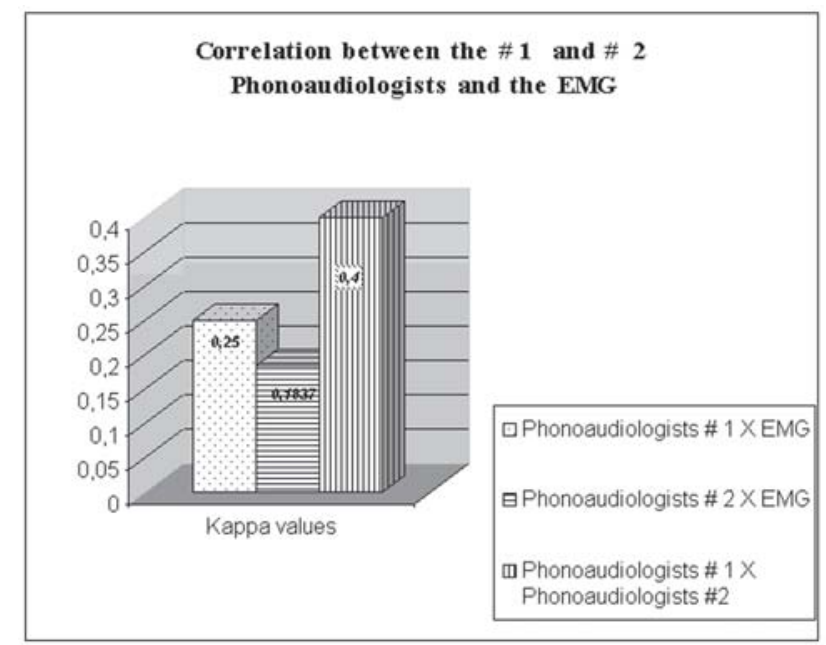

FIGURE 1- Graphic analysis of palpation and EMG events of the masseter muscle
2,000 Hz, Butterworth type filter, low-pass of $500 \mathrm{~Hz}$ and high-pass of $20 \mathrm{~Hz}, 100$ times gain, managed by a data acquisition program belonging to the Department of Morphology from Piracicaba Dental School - FOP/ UNICAMP. The software Aqdados was used for digital signal acquisition and file storage.

The electrodes were positioned on the masseter muscle bilaterally, parallel to the muscle fibers, with their silver bars perpendicular to the fibers to maximize capture and minimize noise interference. The electrodes were positioned on the skin, which was previously cleaned with gauze soaked in $70 \%$ alcoholic solution, with the purpose of removing impurities and grease in order to reduce the skin electrical resistance. They were attached with double face adhesive tape.

In order to guarantee the correct bilateral positioning of the electrodes on the masseter muscle, the muscular function test was performed so as to prevent errors in the differential active electrodes repositioning (De Luca ${ }^{10}$, 1997). The masseter muscle is easily identified through palpation, when asking the volunteer to perform forced maximal intercuspation. The electrode was then attached to the region of greater volume.

The ground electrode was attached to the anterior region of the distal portion of the volunteer's forearm with a velcro tape, and it was connected to one of the electromyograph channels. The ground electrode purpose is to minimize, or rather, eliminate the electromyographic record noises.

\section{COLLECTION OF ELECTROMYOGRAPHIC DATA}

The EMG laboratory was set at a constant temperature of $24^{\circ} \mathrm{C}\left( \pm 2^{\circ} \mathrm{C}\right)$. The next step was to prepare volunteers. Their body temperature was also observed, i.e., it could not exceed $38^{\circ} \mathrm{C}$, meaning that the volunteer could be feverish, according to the guidelines suggested by Turkey ${ }^{23}$ (1993).

The individuals were comfortably positioned on a chair with their back resting towards the back of the chair, their Frankfurt plane parallel to the ground, open eyes looking straight towards the infinite, feet on the ground, and arms resting on the inferior limbs. This step began with a brief explanation of the research.

The volunteers were trained and instructed to perform habitual maximal intercuspation of teeth with Parafilm M. ${ }^{\circledR}$.

The isometric mastication register was performed. The signal acquisition would only be done when the patient was able to perform a stable level of contraction for 15 seconds.

The electromyographic signals registered were stored in the computer memory files and also in a CD for further analysis (off-line).

\section{DATA ANALYSIS}

\section{STATISTICAL ANALYSIS}

The technique used was Kappa statistical test, a non- 
parametric test that aimed to compare the ratios of the same variable measured in a nominal level in two different occasions. The reproducibility of the results is tested admitting that there will be agreement on the answers ratios in both periods considered. The data are inserted in a text box, in the $2 x 2$ contingency form.

\section{ETHICAL ASPECTS}

The present research was submitted to the FCM/ UNICAMP Ethics Committee under record file ${ }^{\circ}$ 415/2002, for ethical analysis regarding the Resolution 196/96 of the National Health Council on October 10, 1996.

\section{RESULTS}

In this chapter, the results will be featured in Tables (1, 2, and 3), which represent possible correlations between the performed events.

Through the data shown it is possible to observe that the agreement between palpation assessment and electromyographic signal was $25 \%$ comparing examiner 1

TABLE 1-Agreement between palpation of speech therapist 01 and EMG

Electromyography

Right Left

$\begin{array}{llll}\text { Speech therapist } 01 & \text { Right } & 8(33.33 \%) & 4(16.66 \%) \\ & \text { Left } & 5(20.83 \%) & 7(29.16 \%)\end{array}$

$($ Kappa $=0.2500)$

TABLE 2-Agreement between palpation of speech therapist 02 and EMG

\section{Electromyography}

Right Left

$\begin{array}{llll}\text { Speech therapist 02 } & \text { Right } 6(25 \%) & 3(12.5 \%) \\ & \text { Left } \quad 7(29.16 \%) & 8(33.33 \%)\end{array}$

$($ Kappa $=0.1837)$

TABLE 3- Agreement between palpation of speech therapists 01 and 02

\begin{tabular}{lllc} 
& & \multicolumn{2}{c}{$\begin{array}{c}\text { Speech therapist 02 } \\
\text { Right }\end{array}$} \\
& & Left \\
\hline Speech therapist 01 & Right & $9(30 \%)$ & $6(20 \%)$ \\
& Left & $3(10 \%)$ & $12(40 \%)$ \\
\hline
\end{tabular}

$($ Kappa $=0.4000)$ and electromyography (Table 1), according to Kappa test. The agreement between examiner 2 and EMG was 18\%, while the agreement between examiners was $40 \%$ (Table 3 ).

In order to better illustrate the correlation between the data obtained comparing palpation and electromyographic assessment, and palpation between examiners, the following graph is shown:

\section{DISCUSSION}

At first, no comparison can be made to the literature regarding the correlation between palpation assessment of the masseter muscle and electromyography.

\section{CONSIDERATIONS ABOUT \\ KINESIOLOGICAL \\ ELECTROMYOGRAPHY}

The kinesiological electromyography is a technique used by many health professionals to study the muscular response related to specific activities.

The electromyographic signal captured on the muscle surface represents the manifestation of the neuromuscular system activation associated with muscle contraction (Basmajian and De Luca², 1985). The signal amplitude is highly sensitive towards physical factors related to the electric activity capture (electrode configuration, impedance of the electrode/skin, location, etc.), as well as the physiological and anatomical structure characteristics of each muscle (area of transverse section of fibers, fiber type, recruitment sequence, etc.), as reported by Mathiassen, et al. ${ }^{16}$ (1995); therefore, it is highly reliable.

According to De Luca $^{10}$ (1997), two factors have a stronger influence upon the electromyographic signal:

A) Stability of the motor unit activation pattern;

B) Stability of the electrode in regard to the active muscle fibers, which requires a high level of demand during electrode placement.

\section{VARIATIONS BETWEEN EXAMINERS AND ELECTROMYOGRAPHY}

It can be observed that there was a positive correlation between examiners and EMG, however, as the minimum significance index was not achieved (75\%), it is impossible to confirm that palpation can substitute the electromyographic exam.

Cram, et al. ${ }^{9}$ (1986) performed a study that compared the kinesiological electromyography parameters in regular subjects, as well as in subjects with a history of previous occurrences of chronic pain in masticatory muscles. The results confirm that patients with chronic pain feature a high level of electromyographic activity when compared to the control group. 
The EMG signal expresses a method of recording the electrical activity of muscles when they contract (Amadio and Duarte $\left.{ }^{1}, 1996\right)$.

It is important to remember that both evaluations also have their importance upon clinical and scientific practice. According to Okeson ${ }^{18}$ (1992), digital palpation is a widely accepted technique in determining muscular tone and pain.

\section{THE ROLE OF MUSCULAR PALPATION}

Palpation gives us data about volume, position, muscular symmetry, and mainly about painful spots in the muscle. It should be initiated in a smooth manner so it would not cause any intense pain (Bianchini ${ }^{4}(1998)$ ). As stated by Felicio ${ }^{12}$ (1999), palpation of the elevator and depressor mandible musculature completes the assessment of the stomatognathic system.

Through the results obtained in the sample, it is observed that palpation is an evaluation method that cannot substitute electromyographic assessment regarding muscle tension assessment. However, it plays an important role in clinical assessment, representing a very useful tool for speech therapists, physical therapists, dentists, and doctors, as well as for all health professionals as a complementary assessment.

It is understood as a concept of sovereign clinic, the act of a "higher clinical procedure" (seeing the patient as a whole organism) that starts with the analysis to detect the problem to the complete cure of the patient, with data in each step, information to which the examiner must pay attention, each detail, situation and subjective clinical judgment that enriches the process of making a decision. Subjectivity is always present, even when denied; recognizing its existence and importance to use it better is the element that sets apart the objective/subjective concepts (Moyses and Collares, 1997).

The present study reinforces this idea when focus on the importance of joining to an objective evaluation, such as EMG, to the clinical speech therapy look, where the subjectivity, such as palpation, supplies the professionals with personal elements and personal knowledge and judgment to make a decision. In the relationship between professional and patient there are verbal elements, which allow "reading" of the therapeutic process, restructuring attitudes along treatment.

\section{PERSONAL VARIATIONS BETWEEN THE EXAMINERS}

It was observed, even between the examiners, that they did not reach agreement in palpation. There was 40\% correlation between them, which was observed by Kappa statistical test. This shows that the palpation sensitivity of each examiner may greatly vary, interfering on the results and therapy. Due to the professionals' experience and individuality, along with their beliefs about physiopathology, the form of applying the technique justifies the difference of each examiner regarding the electromyographic assessment, remarking that both assessments (palpation and EMG) must be complementary, thus avoiding possible errors in therapeutics.

\section{CONCLUSION}

The results of the present study considering the experimental conditions used allow to conclude that:

1) The correlation levels were low on the results obtained between examiners (40\%);

2) The correlation between the results collected on the palpation process and the results of the electromyographic exam of the masseter muscle was very low (examiner $1=$ $25 \%$; examiner $2=18 \%$ );

3) The implications of these results indicate that muscular palpation is not appropriate to replace the electromyographic exam in the detection of muscle tension; otherwise, it should be complementary;

4) The association of subjective procedures/methods with objective procedures/methods in speech therapy will provide a more consistent and complete clinical activity.

It is important to highlight that the results must be considered as restricted to the conditions in which the exams occurred (with those specific examiners, that specific way of performing the electromyographic exam and those specific individuals), and no generalization is intended.

The data here obtained may generate and give support to new studies, which, by their turn, will stimulate further and complemented studies in the area.

\section{REFERENCES}

1- Amadio AC, Duarte M. Fundamentos biomecânicos para análise do movimento. São Paulo: Laboratório de Biomecânica EEFUSP; 1996. $162 \mathrm{p}$.

2- Basmajian JV, De Luca CJ. Muscle alive: their function a revealed by electromyography. 5 ed. Baltimore: Willians \& Wilkins; 1985. p. 432-62.

3- Bérzin F. Estudo eletromiográfico da hiperatividade de músculos mastigatórios, em pacientes portadores de desordem crânio-mandibular (DCM) com dor miofascial. In: Anais da $4^{\circ}$ Simpósio Brasileiro e Encontro Internacional Sobre Dor. 1999 abr; São Paulo: 1999. p.405.

4- Bianchini EMG (org). Articulação temporomandibular: implicações, limitações e possibilidades fonoaudiológicas. Carapicuíba: Pró-Fono; 2000

5- Bianchini EMG. Mastigação e ATM. Avaliação e terapia. In: MARCHESAN, I.Q. Fundamentos em fonoaudiologia. Rio de Janeiro: Guanabara Koogan; 1998. p.41.

6- Biasotto-Gonzalez DA, Berzin F. Electromyographic study of patients with masticatory muscle disorders physiotherapeutic treatment (massage). Braz J Oral Sci. 2004;3(6).

7- Biasotto-Gonzalez DA, Berzin F. Estudo eletromiográfico dos músculos do sistema estomatognático durante a mastigação de diferentes materiais. Rev Bras Ciênc Saúde, 2003;1(1):19-25. 
8- Carlson CR, Okeson JP, Falace DA, Nitz AJ, Anderson D. Stretch based relaxation and reduction of EMG activity among masticatory muscle pain patients. J Craniomandib Dis. 1991;5(3):205-12.

9- Clark GT, Beemsterboer PL, Rugh JD. Nocturnal masseter muscle activity and the symptoms of masticatory dysfunction. J Oral Rehabil. 1981;8(3):279-86.

10- Cram JR, Engstrom D. Patterns of neuromuscular activity in pain and nonpain patients. Clin Biofeed Health. 1986;9(2):106-15.

11- De Luca CJ. The use of surface electromyography in biomechanics. J Appl Biomech. 1997;13(2): 35-63.

12- Fehrenbach MJ, Herring SW. Anatomia ilustrada da cabeça e do pescoço. São Paulo: Manole;1996.

13- Felício, M.C. Fonoaudiologia aplicada a casos odontológicos: motricidade oral e audiologia. São Paulo: Pancast; 1999.

14- Jardini RSR. Uso do exercitador facial-um estudo preliminar para fortalecer os músculos faciais. Pró-fono Rev Atual Ci, 2001;13 (1):839.

15- Kendall SP, McCREARY EK. Músculos provas e funções. 3. ed. São Paulo: Manole; 1987.

16- Kennedy V. Palpation. Medical Encyclopedia. Adam Editorial; Out 2001. Disponível em: www.nlm.nih.gov/medilineplus/ency/article/ 002284.htm.

17- Mathiassen SE, Winkel J, Hagg GM. Normalization of surface EMG amplitude from the upper trapezius muscle in ergonomic studies - a review. J Electromyog Kinesiol. 1995;5(4):197-211.

18- Moysés MAA, Collares C.A.L. Inteligência abstraída, crianças silenciadas: as avaliações de inteligência. Psicologia USP, 1997;8(1): 63-89.

19- Naeije M, Hansson TL. Eletromyographic screening of myogenous and arthrogenous TMJ dysfunction patients. J Oral Rehabil. 1986;13(5):433-41.
20- Okeson JP. Fundamentos de oclusão e desordens temporomandibulares. 2a ed. São Paulo: Artes Médicas; 1992.

21- Rodrigues AK. Eletromiografia dos masseteres no apertamento dental e na mastigação em indivíduos com e sem maloclusão. [Dissertação -Mestrado- Pontifícia Universidade Católica de São Paulo].

22- Steenks MH. De Wijer A. Disfunções da articulação temporomandibular do ponto de vista da fisioterapia e da odontologia. São Paulo: Ed. Santos; 1996.

23- Türker KS. Electromyographyc: some methodological problems and issues. Phys Ther. 1993;73(10):698-710.

NAME

Date of Birth: -

Age:

PALPATION EXAMINATION:

MUSCULAR TENSION - ISOMETRIC CONTRACTION

Yes ( ) R $\mathrm{R}$ L ( ) $\quad \mathrm{R}<\mathrm{L}(\quad) \quad \mathrm{R}=\mathrm{L}(\quad)$

No ( )

ELECTROMYOGRAPHY:

ISOTONIC CONTRACTION

Yes ( ) $\mathrm{R}>\mathrm{L}(\mathrm{l}) \mathrm{R}<\mathrm{L}(\quad) \quad \mathrm{R}=\mathrm{L}(\quad)$

No ( ) 


\section{APPENDIX 2}

INFORMED CONSENT FORM TO BE PART OF THE MASTER THESIS

Ivone PANHOCA, PhD Associate Professor, Department of Children and Teenagers Health, State University of Campinas (UNICAMP)

Daiana BIASOTTO, MSc Graduate student (Master degree), Department of Children and Teenagers' Health, State University of Campinas (UNICAMP)

Project: CORRELATION BETWEEN THE CLINICAL SPEECH THERAPY ASSESSMENT AND ELECTROMYOGRAPHIC ACTIVITY OF THE MASSETER MUSCLE

The study aims to correlate the electromyography activity with the clinical evaluation of the masseter muscle through palpation.

I will be submitted to a previous selective evaluation and if selected I will be part of an experimental procedure that will be performed at the Electromyography Lab of the University of Mogi das Cruzes - Mogi das Cruzes-SP. I am aware that I will be reimbursed for any expenses I have due to the participation in the experiment (related to transportation and feeding) and that I can refuse to take part in the research or withdraw my informed consent in any step of the process without suffering any penalty.

The data obtained during this experiment will be restricted and will not be allowed to be reviewed by other people without my written authorization. On the other hand, the data may be used for scientific purposes, keeping, although, my privacy. I assure my participation throughout the whole procedure of the experiment, with the exception of an arising problem that keeps me from taking part in it.

I read and understood the information contained in this contract, as well as the ones contained in the Resolution 196/96 from the National Board of Health.

Mogi das Cruzes,

( Month, Day, Year)

\section{Responsible:}

Ivone PANHOCA, PhD Associate Professor, Department of Children and Teenagers Health, UNICAMP
Daiana BIASOTTO, MSc Graduate student (Master degree), Department of Children and Teenagers Health, UNICAMP

Name of the volunteer

Volunteer's ID number

Phone number: 